\title{
SCLIAR, MOACYR. TERRITóRIO DA EMOÇÃo. SÃO PAUlO: COMPANHIA DAS LETRAS, 2013, 275 P. [PREFÁCIO E SELEÇÃo: Regina Zilberman]
}

\author{
Vicentônio Regis do Nascimento Silva"
}

"Ao fim e ao cabo, a medicina é isso, uma relação especial entre pessoas". (p.34)

"Não dá para vacinar pessoas como se vacina o gado. E não basta conhecer as doenças. É preciso conhecer os seres humanos, e levar em conta suas aspirações e também os seus temores". (p. 71)

A capacidade múltipla de Moacyr Scliar - professor, médico sanitarista, conferencista, cronista, contista, novelista, romancista, ensaísta, articulista de jornais e de periódicos especializados, membro da Academia Brasileira de Letras - revelase novamente em Território da emoção, livro póstumo de crônicas publicadas em suplemento de saúde de Zero Hora (Porto Alegre/RS) entre 1995 e fins da primeira década de nosso século, dividido em seis blocos pela crítica literária Regina Zilberman: Literatura e Medicina, Histórias de médicos, Memórias de um médico, Nosso corpo, Os males que nos afligem e Comportamentos.

O primeiro bloco - Literatura e Medicina
- mira a finalidade terapêutica da cura, ressaltando a leitura obrigatória de obras literárias pelos estudantes antes de lançarem mãos ao diploma. A humanização acontece coletiva e pragmaticamente na medicina. A leitura de grandes autores - Thomas Mann, Tolstoi, Sinclair Lewis, Bernard Shaw, Molière, Érico Veríssimo, Machado de Assis e Jorge Amado - ajudaria os acadêmicos a compreender a necessidade de vislumbrar problemas rotineiros incapazes de, na maioria das vezes, serem eficazmente solucionados pela famosa objetividade científica. A Literatura é terapia tanto para quem lê quanto para quem escreve.

Agrupando experiências sobre desemprego, racismo e ética, Histórias de médicos exprime opiniões ora pitorescas, ora contundentes. Entre as pitorescas, os entreveros de um gastroenterologista $\mathrm{e}$ professor norte-americano após a demissão: tentativas frustradas de reinserção no mercado de trabalho, novo emprego em cargo genérico, condições - profissionais

\footnotetext{
* Doutorando em Letras pela Universidade Estadual de Londrina (UEL). Mestre em História pela Universidade Estadual Paulista Júlio de Mesquita Filho (UNESP), campus Assis. Integrante do grupo de pesquisa "Estudos de Dramaturgia Moderna”, vinculado à UEL, liderado pela Prof ${ }^{a}$. Dra . Sônia Aparecida Vido Pascolati. Contato: vicentonio@live.com
} 
e financeiras - inferiores. Atacando os problemas de empregabilidade - reforçados pelo aumento de vagas nas universidades, número de profissionais proporcionalmente superior ao de habitantes, baixa remuneração - defende a sorte do colega norte-americano se comparada à da faxineira que, diante de mulher em estado grave após acidente automobilístico, comanda trabalhos que salvarão sua vida. Questionada pelo filho da paciente como sabia dos procedimentos, respondeu, em discreto sotaque, que chefiara equipes especializadas em seu país. $O$ ataque à mercantilização da educação superior - destacadamente à abertura desenfreada de cursos de medicina - e ao reaproveitamento de profissionais em outros campos intensifica pitorescamente a ironia: antes mudar de especialidade do que limpar corredores.

A ética transcende valores pessoais, geográficos, políticos e temporais. A contundência do posicionamento contra quem se utilizou da ciência, do conhecimento ou da profissão para acobertar regimes totalitários ou massacrar direitos individuais de pacientes, seja no Brasil - a luta da psicanalista Helena B. Vianna contra diretores da Sociedade Psicanalítica do Rio de Janeiro que colaboraram com a ditadura (O dilema dos analistas, p. 44) - seja no exterior-médicos que promoveram experiências com prisioneiros judeus (Médicos ou monstros?, p. 72) - reflete os percalços entre discurso e prática científicas, determinando o lugar do intelectual na defesa dos direitos fundamentais - considerando direitos fundamentais os que garantem "[...] convivência digna, livre e igual de todas as pessoas" (SILVA, 2004, p. 178).

Os olhos voltam-se à África do Sul para, relatando fato pitoresco, descrever os obstáculos sociais enfrentados por homem branco cuja pele, em decorrência de doença, escurece gradativamente. Se considerado o Apartheid, imaginam-se as situações arriscadas em que se mete em ações simples, como entrar em banheiro de brancos. Por outro lado, de maneira contundente, admira-se o jardineiro negro de universidade na mesma África do Sul. Embora adquira conhecimentos, promova centenas de cirurgias e receba o título de doutor honoris causa, jamais obtém o status de médico. Aposenta-se na condição profissional e salarial de jardineiro (Doação, p. 75). Em moldes semelhantes, os mecanismos de aferição do QI (Quociente de Inteligência) que, nos melhores resultados, atestam os negros quinze pontos atrás dos brancos. Obviamente manipuladas, as pesquisas - ainda realizadas em diversos lugares no século XXI - atrelam-se aos interesses dos brancos ou dos grupos que a concebem (Biologia e preconceito: o caso da sindrome de Down, p.78).

O terceiro bloco - Memórias de um médico - dedica-se à ética na ciência e, principalmente, na conduta médica ao se debruçar sobre a falta de estrutura da saúde pública: a aflição de quem, em determinados casos, recorre às técnicas teatrais. A emoção da emergência discute os limites dos problemas efêmeros, recordando atividades desempenhadas em um posto de saúde pública de onde se desloca frequentemente em um carro caindo aos pedaços. Em um caso, ainda de longe, constata o cadáver à beira 
do rio há horas ou dias. Apesar do óbvio, os curiosos precisam de qualquer ação: "Fizemos a rápida encenação, depois partimos. $O$ que ficava para trás era um retrato da assistência médica no Brasil: muito pouco, muito tarde, e, às vezes, muito ridículo". (p. 96)

Em Nosso corpo, sobressaem os embates entre psiquismo e organismo: na maioria das vezes, o organismo saudável antecede soluções psicológicas/espirituais/cotidianas (Nem sempre o psiquismo é o mais importante, p. 145-147; Humores e hormônios, p. 155-156).

O quinto conjunto - Os males que nos afligem - aproxima-se de temas como depressão (analisando os comportamentos e as angústias maternas no pósparto ou na síndrome do ninho vazio, caracterizada quando os filhos saem de casa), o tragicômico nas relações médico/ paciente (citando ilustrativamente $o$ caso de médico que utiliza o polegar para ensinar o uso de preservativo e, meses depois, marido o culpa pela gravidez da esposa já que literalmente desenrolara o preservativo no dedo), a intertextualidade (dialogando com a mitologia grega - $A$ maratona e a vida, p. 139; A estrada e o pânico, p. 172) e a ponderação filosófica (acerca de esquecimento - Os usos do esquecimento, $\mathrm{p}$. 181; felicidade - Sem medo de ser infeliz, p. 183; melancolia - Entendendo a melancolia, p. 185). Voltando à ética, delimita os âmbitos de atuação da Medicina ampliada metonimicamente às demais ciências - e da política':

\footnotetext{
${ }^{1}$ Exemplo das patológicas relações entre Medicina e Política são relatadas pelo escritor Sérgio Faraco, cujo livro de memórias consta ao fim da resenha.
}

[...] há uma espécie de terra de ninguém, uma região de limites imprecisos, em que o critério de doença está ligado à mentalidade corrente, ou, o que é mais sinistro, à situação política. A psiquiatria soviética estava cheia de tristes, e ilustrativos, casos. Gente que se opunha ao regime e que, recebendo um diagnóstico qualquer, análogo à drapetomania, era sumariamente trancafiada nos hospitais psiquiátricos. A lógica atrás disso era a seguinte: o governo quer o bem-estar de todos os cidadãos. Quem se opõe ao governo só poder estar sofrendo de um distúrbio psiquiátrico. Veredicto: hospício. (p. 168)

Comportamentos aposta na intertextualidade - conversando com Max Weber, Bertrand Russell, Paul Lafargue e Ascenso Ferreira ( $O$ elogio da preguiça, p. 213) assim como com Walter Benjamim, Rousseau, Érico Veríssimo (Os andarilhos da saúde, p. 222) e Pascal (A lógica dos alimentos, p. 228). Diferentemente dos precedentes, este bloco inova na consciência não apenas em comentários ou sugestões, mas, agarrado à experiência de homem público teórico (pesquisador acadêmico e professor) e prático (médico especializado em saúde pública), em debates, discordâncias e propostas de políticas públicas voltadas às drogas (Drogas: a controvérsia, p. 240).

Se, por um lado, a crônica tem finalidades transitórias, por outro, assume a característica da permanência em Território da Emoção, considerando que, boa parte dos temas tratados - o diálogo com escritores, as confluências e os distanciamentos entre 
teorias, práticas e aplicações científicas, as ponderações em torno de religião, política e conhecimento, o resgate das liberdades e das garantias jurídicas fundamentais, o combate ao mercantilismo na saúde e a luta em prol da humanização do ser humano (embora pareça contraditório, nem todo humano se humanizou) - nos textos curtos de linguagem fluida continuarão atuais em trinta ou quarenta anos. Portanto, alcançarão perspectivas que rompem os outrora estereótipos temporais em que injustamente a trancafiaram.

\section{REFERÊNCIAS}

FARACO, S. Lágrimas na chuva. Porto Alegre: L\&PM, 2002.

SILVA, J.A. da.Cursode DireitoConstitucional

Positivo. São Paulo: Malheiros, 2004.

Recebido para publicação em 20 de ago. de 2013 Aceito para publicação em 4 de dez. de 2013 